\title{
Coronary artery bypass grefting after right pneumonectomy
}

\author{
Sağ pnömonektomi sonrası koroner arter bypas greft cerrahisi
}

\author{
Nail Kahraman*, Funda Yıldırım*, Tülün Öztürk**, Adnan Taner Kurdal*, Ihsan Işkesen* \\ *Celal Bayar Üniversitesi Tıp Fakültesi, Kalp ve Damar Cerrahisi AD, Manisa \\ ${ }^{* *}$ Celal Bayar Üniversitesi Tıp Fakültesi, Anesteziyoloji AD, Manisa
}

\begin{abstract}
A 65-year-old male patient with a 12 year old history of right pneumonectomy was admitted to our cardiology unit with chest pain. The patient was referred to our clinic for CABG surgery when coronary disease of the left main artery was diagnosed with coronary angiography. Pulmonary function tests showed restrictive pulmonary disease and the patient went through respiratory physiotherapy and bronchodilatator treatment for a week before surgery. LIMA and saphenous vein grafts were used during the CABG surgery. A shift in the cardiac structures towards the right hemithorax was observed during surgery. The patient was extubated at the 12th hour after surgery and discharged without any complications on the 8th post operative day.
\end{abstract}

Pam Med J 2015;8(1):51-53

Key words: Coronary artery bypass, pneumonectomy.

\section{Özet}

65 yaşında 12 yıl once geçirilmiş sağ pnömonektomi operasyon öyküsü olan erkek hasta göğüs ağrısı yakınması ile kardiyoloji kliniğine kabul edildi. Yapılan koroner anjiografi sonucunda sol ana koroner lezyonu saptanarak kliniğimize koroner arter bypass greft cerrahisi için kliniğimize refere edildi. Solunum fonksiyon testi sonucunda restriktif tip akciğer hastalığına rastlandı. Cerrahi öncesi hastaya bir hafta sure ile solunum fizyoterapisi ve bronkodilatatör tedavisi uygulandı. KABG operasyonu sol internal mamarian arter ve safen ven greftleri kullanılarak yapıldı. Operasyon sırasında mediastinal yapıların sağa kaymış olduğu gözlendi. Hasta postoperative 12. Saatte ekstübe edilerek postoperative 8. Günde komplikasyonsuz taburcu edildi.

Pam Tıp Derg 2015;8(1):51-53

Anahtar sözcükler: Koroner arter bypass, pnömonektomi.

\section{Introduction}

Open heart surgery is a frequent cause of pulmonary dysfunction. Usually forced vital capacity decreases $70 \%$ in the first postoperative day of cardiac surgery and does not increase until the $10^{\text {th }}$ postoperative day. This increase is only $30 \%$ of the previous forced vital capacity. These changes can be easily tolerated in patients with normal pulmonary reserves but after pneumonectomy, nearly $50 \%$ decrease of these reserves makes it harder to tolerate cardiac surgery $[1,2]$. Pneumonectomy can lead to serious physiological, anatomical problems and can cause difficulty for a later open heart surgery. Pulmonary complications related to open heart surgery cannot be easily tolerated in patients with previous pneumonectomy because of limited pulmonary functions and reserves $[3,4]$. Preoperative pulmonary physiotheraphy and bronchodilator treatment should be done to prepare the patient for postoperative respiratory problems. We would like to present a patient with a previous pneumonectomy who went through successful CABG (Coronary Artery Bypass Graft) surgery in our clinic.

\section{Patient and Methods}

A 65-year-old male patient with a history of a 12 year old right pneumonectomy was admitted to our cardiology unit with a serious complaint

Funda Yıldırım

Yazışma Adresi: Celal Bayar Üniversitesi Tıp Fakültesi, Kalp ve Damar Cerrahisi AD, Manisa e-mail: fundanizamoglu@yahoo.com 
of chest pain. Coronary artery disease was diagnosed with coronary angiography and the patient was referred to our clinic for surgery. According to the patient's previous hospital reports, 12 years ago the patient underwent a right pneumonectomy because of bronchial squamous cell carcinoma of the right lung. Clinical findings on physical examination were lack of breath sounds in the right hemithorax while the other systemic signs were normal.

$80 \%$ stenosis of the LMCA (Left Main Coronary Artery) was detected angiographically. Mediastinal structures were shifted to the right as seen on the chest X-Ray (Figure 1) and thorax CT. Arterial blood gas analysis showed a normal $\mathrm{pH}$, mild hypercapnia $\left(\mathrm{PaCO}_{2}=\right.$ $48 \mathrm{mmHg})$, hypoxemia $\left(\mathrm{PaO}_{2}=74 \mathrm{mmHg}\right)$. Respiratory function tests showed $1^{\text {st }}$ second forced expiratory volume of 2,52 $\mathrm{L}$ and forced vital capacity of 3,61 L. Restrictive pulmonary disease was diagnosed.

The patient was taken to surgery after a week of respiratory physiotherapy and bronchodilator treatment. A central venous catheter was placed in the right jugular vein. Endotracheal intubation was carried out with bronchoscopic assistance. A full median sternotomy was made. The LIMA (Left Internal Mammarian Artery) was harvested with difficulty because of adhesions. The aorta and right atrium were displaced towards the right thorax. Cardiac apex was at the midline. Right atrial cannulation was done from the assistant position because of the displacement of the cardiac structures, so that access to the femoral vein was not needed. Cardiopulmonary bypass was done with moderate systemic hypothermia $\left(32^{\circ} \mathrm{C}\right)$. Cardiac arrest was obtained with antegrade cardioplegia administration. Topical cooling was not used to avoid the risk of phrenic nerve damage. LIMA-LAD (Left Anterior Descending Artery) and Aort to Left Circumflex Artery bypass with saphenous vein were completed. CPB was terminated with no complications. Postoperative follow up was eventless and the patient was discharged on the $8^{\text {th }}$ postoperative day.

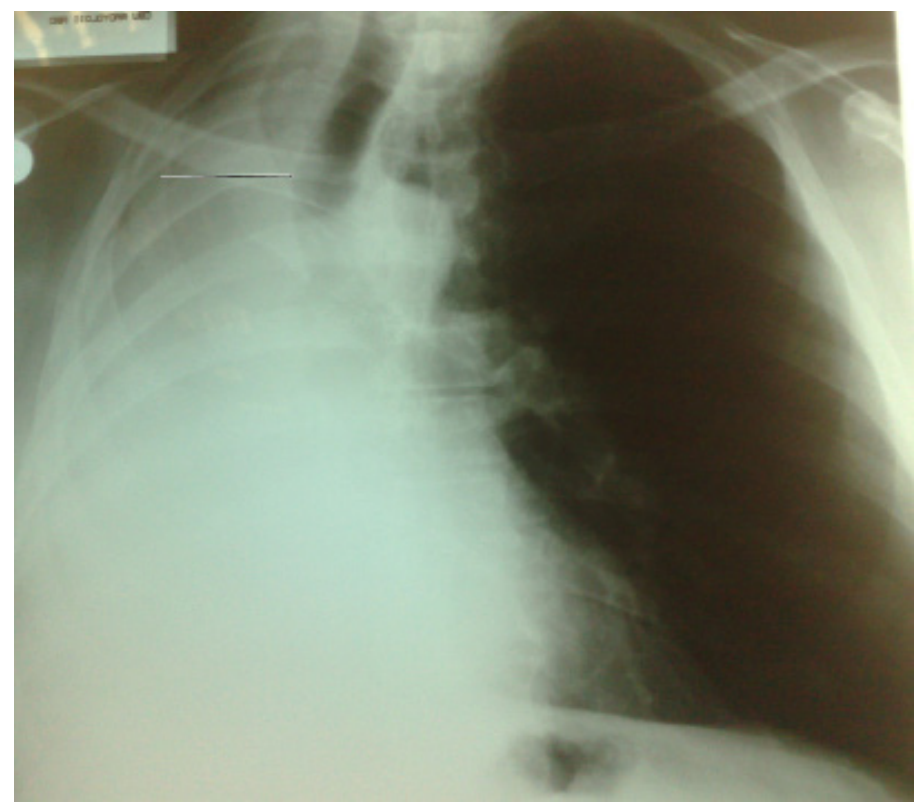

Figure 1. Preoperative chest X-Ray

\section{Discussion}

Decreased respiratory functions after pneumonectomyareindanger offurtherdecrease after CABG surgery. Although increased appearance of pulmonary complications has been reported, mortality because of pulmonary problems in pneumonectomy patients who have under gone CABG surgery has not been reported. For this reason open heart surgery is not contraindicated in this special situation but detailed preoperative evaluation of pulmonary functions is necessary. In patients with a previous pneumonectomy or lobectomy when open heart surgery is planned, special attention for decreased vital capacity, positional changes of mediastinal structures and the heart should be considered [5]. Related to positional changes, careful preparation for difficult intubation is necessary. In our case intubation was performed with bronchoscopic assistance.

Decrease of pulmonary functions, pulmonary reserve, ventilation-perfusion rates, pulmonary capillary pressure and increased airway resistance after pneumonectomy is expected. 
Although these changes are mild with a single lobectomy, pneumonectomy could cause an increase in these problems [6,7]. Pulmonary rehabilitation prior to surgery is necessary in order to decrease surgical morbidity. In addition to pulmonary physiotherapy, bronchodilatator and mucolytic treatment should be started before surgery. In our case pulmonary rehabilitation, bronchodilatator and mucolytic treatment was started a week before surgery and no postoperative pulmonary complications were observed.

In patients with a single lung, a central venous catheter should be placed from the pneumonectomy side in order to avoid occurrence of pneumothorax, pleura of the opposite site should also be opened and a chest tube should be placed into that side as in our patient [8].

Positional changes of the heart should also be carefully evaluated and dissection and cannulation should be done with caution $[5,7]$. In our patient, the right atrium was deviated to the right side and it was very difficult to perform the right atrial cannulation from the surgeon's side, so we performed the right atrial cannulation from the assistant side of the operating table. When we achieved this right atrial venous cannulation, we did not prefer femoral vein cannulation. Since the LIMA was suitable for LAD bypass, we did not need to use the RIMA (Right Internal Mammary Artery). Topical cold saline application should be avoided as in our patient, to prevent phrenic nerve injury.

Early mobilization of the patient can decrease the development of atelectasis and deep vein thrombosis [8]. Postoperative pulmonary physiotherapy is necessary to prevent atelectasis. Bronchodilatators, steroids and diuretics should be administered to decrease the development of bronchospasm and pulmonary congestion. Postoperative pain can decrease pulmonary functions, thus, use of non-steroid anti-inflammatory drugs for pain management is recommended. Beta blockers should be avoided because of the risk of bronchospasm. After the surgery the patient should be ventilated with low pressure and long term ventilation should be avoided because of the risk of barotrauma [1]. Our patient was extubated at the $12^{\text {th }}$ hour postoperatively.

Patients with a previous right pneumonectomy present important surgical challenges. In this group of patients important limitations are the shift of the mediastinum to the right, the length of the LIMA and its position across the hyperinflated left lung. The use of the LIMA as a conduit for CABG in patients after a pneumonectomy is also an important subject. The prerequisite for using a LIMA in these patients is the sufficient length for an in situ LIMA to reach the desired anastomotic site on the coronary artery. In addition to the harvesting of the LIMA the risk of decreased pulmonary functions and phrenic nerve damage is increased, therefore, widespread use of venous grafts after pneumonectomy has been reported $[5,7,9]$.

As a result; patients in need of CABG surgery after pneumonectomy are an increased risk of morbidity. Bronchodilatator treatment and respiratory physiotherapy are required before surgery. During intubation and surgical exposure, several difficulties may be encountered due to the displacement of the middle mediastinal structures after pneumonectomy especially for the institution of cardiopulmonary bypass, arterial and venous cannulations.

THERE IS NO RELATIONSHIP OF SELFINTEREST BETWEEN THE WRITER AND ANY FINANCIAL INSTITUTION IN THIS STUDY

Conflict of interest: The authors declared no conflict of interest.

\section{References}

1. Yazicioglu L, Aral A, Uymaz O, Akalin H: Coronary artery bypass surgery in a patient with a functional single lung. Asian Cardiovascular Thorac Ann. 2005;13(4):377-9.

2. Kopec SE, Irwin RS, Umali-Torres CB, Balikian JP, Conlan AA: The postpneumonectomy state. Chest ,1998;114:1158-1184.

3. Medalion B, Elami A, Milgalter E, Merin G: Open heart operation after pneumonectomy. Ann Thorac Surg ,1994;58:882-884.

4. Fragkidis A, Dimitriou A, Dougenis D. Coronary artery bypass grafting and/or valvular surgery in patients with previous pneumonectomy. J Cardiothorac Surg. 2012;7:110-116

5. Zhao BQ, Chen RK, Song JP. Coronary artery bypass grafting after pneumonectomy. Tex Heart Inst J. 2008;35:470-471.

6. Berrizbeitia LD, Anderson WA, Laub GW, McGrath LB: Coronary artery bypass grafting after pneumonectomy. Ann Thorac Surg, 1994;58:1538-1540.

7. Hulusi Us M, Arslan Y, Ozbek C, (et al.): Coronary artery bypass grafting after left pneumonectomy. J Cardiothorac Vasc Anesth, 2006 ;20:709-711.

8. Ghotkar SV, Aerra V, Mediratta N. Cardiac surgery in patients with previous pneumonectomy. J Cardiothorac Surg. 2008;3:11.

9. Diab KA, Khatib MF, Obeid M, Jamaleddine GW. Coronary artery bypass grafting after pneumonectomy. Eur J Cardiothorac Surg. 2001;19:362-364. 